\title{
Optimalisasi Peran Bantuan Hukum Timbal Balik dalam Pengembalian Aset Hasil Tindak Pidana Korupsi
}

\author{
Khoirur Rizal Lutfi ${ }^{\star}$ Retno Anggoro Putri ${ }^{\star \star}$ \\ Fakultas Hukum Universitas Pembangunan Nasional Veteran \\ Jakarta \\ *irul.rizal@upnvj.ac.id \\ ${ }^{\star \star}$ retnoanggoro17@gmail.com
}

\begin{abstract}
One of the unresolved legal issues in Indonesia is corruption. The problem of law enforcement is not yet optimal so that the assets resulting from criminal acts of corruption which are often in excess of national territory make it difficult to return. Mutual Legal Assistance in Criminal Matters, abbreviated as MLA, which is expected to help law enforcement is not yet optimal. Indonesia, as a participant country of the United Nations Convention Againts Corruption (UNCAC), does not yet have a regulatory framework that comprehensively regulates the aspects recommended by the convention. This study aims to find out about efforts and mechanisms to optimize the role of MLA in the recovery of assets resulting from criminal acts of corruption in Indonesia, especially those abroad. This research is a normative juridical research conducted by library research and interviews with informants related to the legislation and comparison approach. This article concludes that optimizing the role of MLA requires several steps such as implementing MLA in a more detailed technical format, optimizing the role of law enforcement as the implementer and adopting the concept of Non-Conviction Based Asset Forfeiture (NCB).
\end{abstract}

Keywords: Mutual Legal Assistance; Non-Conviction Based Asset Forfeiture; corruption. 


\section{Abstrak}

Salah satu persoalan hukum yang belum terselesaikan di Indonesia adalah korupsi. Masalah belum optimalnya penegakan hukum hingga aset hasil tindak pidana korupsi yang seringkali berada melampaui batas wilayah negara sehingga menyulitkan pengembaliannya acapkali menjadi persoalan tersendiri. Pelaksanaan kerjasama Bantuan Hukum Timbal Balik (Mutual Legal Assistance) disingkat MLA yang diharapkan membantu penegak hukum pun dirasa belum optimal. Sebagai negara peserta United Nations Convention Againts Corruption (UNCAC), Indonesia belum memiliki kerangka regulasi yang mengatur secara komprehensif aspek-aspek yang direkomendasikan konvensi tersebut. Penelitian ini bertujuan untuk mengetahui tentang upaya dan mekanisme optimalisasi peran MLA dalam pengembalian aset hasil tindak pidana korupsi di Indonesia terutama yang berada di luar negeri. Artikel ini merupakan hasil penelitian yuridis normatif yang dilakukan dengan cara studi kepustakaan dan wawancara terhadap narasumber terkait, dengan pendekatan perundang-undangan dan perbandingan. Artikel ini menyimpulkan bahwa untuk optimalisasi peran MLA diperlukan beberapa langkah seperti menerapkan MLA dalam format teknis yang lebih detail, optimalisasi peran penegak hukum sebagai pelaksananya, dan adopsi konsep Non-Conviction Based Asset Forfeiture (NCB) sebagai muatan substansi MLA.

Kata kunci: Bantuan Hukum Timbal Balik; Non-Conviction Based Asset Forfeiture; tindak pidana korupsi.

\section{A. Pendahuluan}

Artikel ini membahas peran Bantuan Hukum Timbal Balik atau yang lebih popular disebut Mutual Legal Assistance (MLA) dalam pengembalian aset hasil tindak pidana korupsi dan optimalisasinya dalam konteks Indonesia. Pembahasan persoalan ini menjadi perlu karena persoalan korupsi yang merupakan masalah serius, sehingga berbagai ikhtiar dan formulasi untuk menyelesaikan atau memberantasnya penting diupayakan. Dalam artikel ini, upaya itu didorong melalui optimalisasi MLA dan peran penegak hukumnya, serta adopsi konsep perampasan aset melalui pendekatan NonConviction Based (NCB) Asset Forfeiture sebagai muatan substansi 
MLA.

Sebagaimana diketahui, korupsi masih menjadi masalah bagi Indonesia hingga saat ini. Korupsi merupakan tindak pidana yang menyebabkan kerugian keuangan negara serta melanggar hakhak sosial maupun ekonomi yang terjadi secara sistemik. ${ }^{1}$ Korupsi secara signifikan merugikan hingga mampu mengurangi kapasitas negara dalam membangun perekonomian dan menyediakan fasilitas kesesejahteraan sosial, sehingga pengembalian aset maupun keuangan negara yang dikorupsi tentu perlu menjadi konsens sebagai upaya optimalisasi penegakan hukum dalam tindak pidana korupsi.

Sebagai salah satu bentuk komitmen terhadap pemberantasan korupsi, Indonesia telah meratifikasi Konvensi Persatuan BangsaBangsa tentang Anti Korupsi atau United Nations Convention Against Corruption (UNCAC) melalui Undang-Undang Nomor 7 tahun 2006 tentang Pengesahan United Nations Convention Against Corruption 2003. UNCAC ini menjadi penting karena berisi serangkaian panduan dalam melaksanakan pemberantasan korupsi, meliputi upaya pencegahan, perumusan jenis-jenis kejahatan yang termasuk korupsi, proses penegakan hukum, ketentuan kerjasama internasional serta mekanisme pengembalian aset terutama yang bersifat lintas negara. $^{2}$

Menurut Mada Apriandi Zuhir, masih terdapat sejumlah hal terkait korupsi yang belum diatur Indonesia meskipun beberapa sudah masuk dalam program legislasi nasional (prolegnas) di Dewan Perwakilan Rakyat (DPR) yang salah satunya adalah isu terkait asset recovery. Dalam buku komitmen Indonesia pada UNCAC dan G20 Anti-Corruption Working Group (ACWG) Tahun 2012-2018 disebutkan, dari 32 rekomendasi hasil review UNCAC putaran pertama, Indonesia baru menyelesaikan sekitar delapan rekomendasi,

1 Nyoman Serikat Putra Jaya, Beberapa Pemikiran ke Arah Pengembangan Hukum Pidana (Bandung: Citra Aditya Bakti, 2008), hlm. 57.

2 Mada Apriandi Zuhir, "United Nations Convention Against Corruption, Kewajiban Internasional dan Diplomasi Indonesia terkait Komitmen anti Korupsi”, makalah Seminar Diseminasi United Nations Convention Against Corruption (UNCAC), diselenggarakan Fakultas Hukum Universitas Sriwijaya dan Komisi Pemberantasan Korupsi, 11 Juni 2020. 
sedangkan dari 21 rekomendasi hasil review putaran kedua, Indonesia baru menyelesaikan sekitar 13 rekomendasi. Beberapa isu prioritas yang diidentifikasi oleh Komisi Pemberantasan Korupsi (KPK) yang perlu diselesaikan antara lain: penyelesaian revisi Undang-Undang Bantuan Hukum Timbal Balik dalam Masalah Pidana (MLA); penguatan independensi dan kelembagaan lembaga anti korupsi; dan penyelesaian Rancangan Undang-Undang (RUU) Perampasan Aset. ${ }^{3}$

Beberapa kasus juga memberikan gambaran bahwa aset-aset yang ditempatkan pelaku korupsi di luar negeri sebagai modus untuk menghilangkan jejak juga menjadi persoalan tersendiri. ${ }^{4}$ Sebagai dampaknya, upaya melacak serta mengembalikan aset tersebut menjadi sulit dilakukan. Terdapat kesenjangan proses penegakan hukum karena di satu sisi pelaku korupsi mampu dengan lebih mudah melintasi dengan bebas batas yurisdiksi dan geografis antarnegara, sementara penegak hukum sendiri tidak mudah menembus batasbatas yurisdiksi dan melakukan penegakan hukum di bawah yurisdiksi negara lain. Sebagai upaya mempermudah proses penegakan hukum ini, negara-negara saling melakukan kerjasama internasional yang salah satunya menggunakan mekanisme bantuan hukum timbal balik dalam masalah pidana atau yang disebut sebagai Mutual Legal

3 Zuhir, "United Nations Convention Against Corruption".

4 Beberapa kasus terkini yang juga disorot yaitu kasus e-KTP di 2017 lihat dalam https:/ / www.lampost.co/berita-kpk-kejar-aset-hasil-korupsi-ktpel-di-luar-negeri.html dan kasus Jiwasraya 2020, dalam https://nasional. kompas.com/ read/2020/01/22/21231531/ kejagung-pastikan-ada-asetmilik-tersangka-jiwasraya-di-luar-negeri?page=all. Beberapa data kasus yang lebih lama Kompas di tahun 2012 mengungkapkan, seperti kasus mafia pajak Gayus Tambunan yang Kejaksaan Agung menyebut ada di empat Negara selain kekayaan senilai Rp 74 miliar dalam bentuk emas, mata uang dollar AS, dan dollar Singapura, kasus wisma atlet M. Nazarudin bahwa sejumlah 5 juta dollar AS, 2 juta euro, dan 3 juta dollar Singapura di Singapura, Hendra Rahardja dalam kasus BLBI sejumlah 493.647 dollar AS di Australia (sudah diserahkan pihak Australia ke Indonesia) dan Robert Tantular dalam kasus dana talangan Bank Century yang menyebutkan ada aset Bank Century senilai lebih dari Rp 6 triliun di Hongkong ditengarai dilarikan Robert Tantular. Lihat dalam Ridwan Arifin, Indah Sri Utari, Heri Subondo, "Upaya Pengembalian Aset yang Berada di Luar Negeri (Asset Recovery) dalam Penegakan Hukum Pemberantasan Korupsi di Indonesia”, Indonesian Journal of Criminal Law, 1, 1 (2016), hlm. 110. 
Assistance in Criminal Matters.

MLA merupakan salah satu bentuk perjanjian yang dilakukan antarnegara yang umumnya difokuskan untuk memberantas kejahatan transnasional yang terorganisasi, seperti narkotika, pencucian uang, dan sebagainya. Hal ini menunjukkan bahwa secara operasional penegakan hukum melalui MLA memang hanya dimungkinkan untuk kejahatan yang memiliki aspek transnasional dan memenuhi asas kejahatan ganda (double criminality). Maksud dari asas double criminality adalah kejahatan atau peristiwa pidana yang sama-sama diakui sebagai kejahatan oleh para pihak. ${ }^{5}$

Sedangkan jika dilihat dalam aspek substansi pengaturanya, UNCAC juga memberi peluang untuk lebih memudahkan pengembalian aset hasil korupsi yang terhalang karena prinsip kerahasiaan bank, selama negara tempat uang disimpan juga meratifikasi UNCAC. Seperti yang tertuang dalam Pasal 40 UNCAC yang menyatakan agar setiap negara pihak memastikan terdapatnya mekanisme yang layak dalam sistem hukum nasionalnya untuk mengatasi kemungkinan halangan-halangan yang timbul dari Undang-Undang Kerahasian Bank atas proses penegakan hukum terhadap kasus-kasus pidana yang ditentukan dalam UNCAC. ${ }^{6}$ Bahkan mekanisme perampasan aset tindak pidana menjadi salah satu norma yang dimasukkan dalam UNCAC 2003 agar negaranegara pihak memaksimalkan upaya perampasan aset hasil kejahatan tanpa melalui proses tuntutan pidana. ${ }^{7}$

Meskipun tercatat sebagai salah satu negara yang meratifikasi UNCAC, Indonesia masih memiliki beberapa persoalan yang harus diselesaikan seperti kerangka regulasi yang belum cukup mengatur

5 Irma Sukardi, "Mekanisme Bantuan Timbal Balik dalam Masalah Pidana (Mutual Legal Assistance) dalam Perampasan Aset Hasil Tindak Pidana Korupsi Berdasarkan Undang-Undang Nomor 1 Tahun 2006 tentang Bantuan Timbal Balik dalam Masalah Pidana (tesis, Universitas Indonesia, Jakarta 2012), hlm. 19.

6 Yasonna H. Laoly, Diplomasi Mengusut Kejahatan Lintas Negara (Jakarta: Pustaka Alvabet, 2019), hlm. 133.

7 Refki Saputra, “Tantangan Penerapan Perampasan Aset Tanpa Tuntutan Pidana (Non-Conviction Based Asset Forfeiture) dalam RUU Perampasan Aset di Indonesia”, Jurnal Antikorupsi Integritas, 3, 1 (2017), hlm. 118. 
skema pengembalian aset dan regulasi teknisnya. Selain itu di kalangan ahli hukum juga masih memperdebatkan efektivitas perampasan aset tanpa pemidanaan untuk kasus korupsi dan menempatkan isu hubungan aset hasil kejahatan dengan pelaku kejahatan sebagai salah satu persoalan mendasar. Melihat persiapan RUU Perampasan Aset Tindak Pidana yang saat ini masih bergulir di Indonesia sementara terdapat kebutuhan segera untuk menemukan jalan alternatif pengembalian aset hasil tindak pidana korupsi melalui mekanisme yang efektif, maka kajian terhadap optimalisasi langkah-langkah terutama mekanisme MLA untuk pengembalian aset tindak pidana korupsi ini sangat relevan dilakukan.

Terkait dengan MLA, Muhammad Rustamaji dan Bambang Santoso mengungkap bahwa ada relasi positif antara bantuan hukum timbal balik dan upaya pengembalian aset hasil tindak pidana korupsi. Penelitian ini juga mencoba memberikan pandangan format MLA dalam upaya pengembalian aset hasil korupsi dengan berdasar pada pendekatan penal. Selain itu penelitian ini juga memberikan ulasan mengenai pentingnya upaya optimalisasi institusi-institusi yang memiliki fungsi penegakan hukum. ${ }^{8}$

Sedangkan dalam aspek substansinya, Dwidja Priyatno memandang pentingnya perampasan aset melalui mekanisme NCB atau tanpa pemidanaan. Menurutnya hal tersebut menjadi proses yang penting untuk segera dituangkan dalam regulasi di Indonesia. Selain itu upaya langkah teknis yang harus dilaksanakan menurutnya adalah memperkuat kerjasama internasional. ${ }^{9}$ Senada dengan hal tersebut, Ridwan Arifin, Indah Sri Utari, dan Heri Subondo lebih menekankan pada aspek teknis pelaksanaan bahwa upaya yang dilakukan dapat melalui jalur formal maupun informal. Jalur formal maksudnya adalah jalur pembentukan regulasi dan penerapan MLA, sedangkan jalur informal adalah pendekatan hubungan diplomatik.

8 Muhammad Rustamaji dan Bambang Santoso, "The Study of Mutual Legal Assistance Model and Asset Recovery in Corruption Affair", Indonesian Journal of Criminal Law, 4, 2 (2019), hlm. 160.

9 Dwidja Priyatno, "Non Conviction Based (NCB) Asset Forfeiture for Recovering the Corruption Proceeds in Indonesia", Journal of Advanced Research in Law and Economics, 9, 1 (2018), hlm. 219. 
Tulisan ini berupaya melengkapi, mengkonfirmasi hingga memberikan perspektif lain tentang aspek-aspek apa saja yang perlu dilakukan untuk optimalisasi peran MLA dalam pengembalian aset. Dalam membahas optimalisasi pengembalian aset hasil tindak pidana korupsi di luar negeri dengan jalan optimalisasi peran MLA, artikel ini difokuskan untuk membahas upaya-upaya konkret dalam rangka optimalisasi peran MLA dalam pengembalian aset hasil tindak pidana korupsi karena didasarkan atas kendala-kendala yang diungkapkan melalui wawancara oleh pelaksana MLA. Hal ini perlu dilakukan karena aparat penegak hukumlah yang dalam tataran praksis menggunakan berbagai MLA baik yang berbentuk bilateral maupun multilateral. Bagian berikutnya membahasnya optimalisasi MLA melalui adopsi prinsip Non-Conviction Based (NCB) Asset Forfeiture, yaitu pengembalian aset dengan pendekatan perdata. Bahasan bagian akhir ini perlu didorong karena Indonesia sebenarnya telah meratifikasi UNCAC namun belum memiliki kerangka regulasi yang komprehensif dalam mengatur skema pengembalian aset tanpa pemidanaan tersebut.

\section{B. Peran Bantuan Hukum Timbal Balik dalam Pengembalian Aset Hasil Korupsi}

Bagian ini membahas peran Bantuan Hukum Timbal Balik (MLA) dalam pengembalian aset hasil korupsi. MLA sendiri pada umumnya ditempuh melalui perjanjian MLA antar negara, baik secara bilateral maupun multilateral. Beberapa perjanjian MLA yang bersifat multilateral relatif sulit dilaksanakan karena persoalan penuangan klausul teknis yang lebih terperinci, sehingga format perjanjian MLA secara bilateral dinilai lebih efektif. Dalam praktiknya di Indonesia, perjanjian MLA yang dibentuk secara bilateral melibatkan gabungan tim yang beranggotakan berbagai instansi seperti Kementerian Luar Negeri, Kementerian Hukum dan Hak Asasi Manusia, Kepolisian dan Kejaksaan Agung untuk melakukan negosiasi terhadap isi perjanjiannya. Suatu kesepakatan dalam perjanjian ini berdasarkan peraturan MLA mengikat para pihak sehingga wajib dipatuhi dan 
dilaksanakan, sebagaimana berlakukanya asas pacta sunt servanda.

Hingga saat ini beberapa perjanjian bilateral berkaitan dengan MLA dijalin oleh pemerintah Indonesia dengan beberapa Negara. ${ }^{10}$ Salah satunya adalah perjanjian antara Indonesia-Australia. Perjanjian ini ditandatangani di Jakarta pada 27 Oktober 1995, namun baru diratifikasi pada 1999 melalui Undang-Undang Nomor 1 Tahun 1999 tentang Pengesahan Perjanjian antara Republik Indonesia dan Australia mengenai Bantuan Hukum Timbal Balik dalam Masalah Pidana (Treaty Between The Republic of Indonesia and Australia on Mutual Legal Assistance in Criminal Matters).

Setelah Perjanjian antara Indonesia dan Australia, Indonesia juga mengadakan perjanjian bilateral dengan Republik Rakyat Cina (RRC), atau yang sekarang di Indonesia disebut Republik Rakyat Tiongkok. Perjanjian MLA ini ditandatangani pada 24 Juli 2000 di Jakarta dan diratifikasi Indonesia melalui Undang-Undang Nomor 8 Tahun 2006 tentang Pengesahan Perjanjian antara Republik Indonesia dengan Republik Rakyat Cina mengenai Bantuan Hukum Timbal Balik dalam Masalah Pidana (Treaty Between The Republic of Indonesia and The People's Republic of China on Mutual Legal Assistance in Criminal Matters).

Perjanjian antara Indonesia dan Pemerintah Daerah Administrasi Khusus Hong Kong Republik Rakyat Cina juga ditandatangani pada tanggal 3 April 2008. Berselang empat tahun kemudian, perjanjian ini baru diratifikasi melalui Undang-Undang Nomor 3 Tahun 2012 tentang Pengesahan Persetujuan Pemerintah Republik Indonesia dan Pemerintah Daerah Administrasi Khusus Hong Kong Republik Rakyat Cina tentang Bantuan Hukum Timbal Balik dalam Masalah Pidana (Agreement Between The Government of The Republic of Indonesia and The Government of The Hong Kong Special Administrative Region of The People's Republic of China concerning Mutual Legal Assistance in Criminal Matters).

Setelah itu berturut-turut dilakukan perjanjian Indonesia

10 Marulak Pardede dan Sri Sedjati, "Efektivitas Perjanjian Kerjasama Timbal Balik dalam Rangka Kepentingan Nasional”, https://www.bphn.go.id/ data/documents/lit_2012_-_7.pdf, diakses pada 28/10/2019, hlm. 6. 
dengan Korea Selatan pada 30 Maret 2002 dan diratifikasi melalui Undang-Undang Nomor 8 Tahun 2014. ${ }^{11}$ Perjanjian yang sama antara Indonesia dan India ditandatangani pada 25 Januari 2011 dan diratifikasi melalui Undang-Undang Nomor 9 Tahun 2014. Perjanjian antara Indonesia dan Vietnam ditandatangani pada 27 Juni 2013 dan diratifikasi melalui Undang-Undang Nomor 13 Tahun 2015. Perjanjian antara Indonesia dan Persatuan Emirat Arab ditandatangani di Abu Dhabi pada 2 Februari 2014 dan diratifikasi dengan UndangUndang Nomor 6 Tahun 2019. Perjanjian antara Indonesia dan Iran ditandatangani pada 14 Desember 2016 di Teheran dan diratifikasi melalui Undang-Undang Nomor 10 Tahun 2019. Perjanjian antara Indonesia dan Konfederasi Swiss yang ditandangani pada 4 Februari 2019 di Bernerhof Bern saat ini masih dalam proses ratifikasi. ${ }^{12}$

Pada sembilan Perjanjian MLA tersebut hampir seluruhnya secara umum bertujuan untuk meningkatkan efektivitas pencegahan sekaligus pemberantasan tindak pidana khususnya yang bersifat transnasional dengan tetap melaksanakan asas penghormatan kedaulatan negara, kesetaraan, dengan mengacu asas double criminality. Namun demikian, meski sudah dijalin kerjasama dengan beberapa negara, sesungguhnya masih terdapat kendala-kendala sehingga pengembalian aset melalui perjanjian MLA menjadi tidak optimal, terlebih jika perjanjian tersebut tidak dituangkan dalam format bilateral. ${ }^{13}$

Perbedaan sistem hukum common law dan civil law dianggap menjadi salah satu kendala di mana common law cenderung pada asas praduga bersalah sedangkan civil law lebih condong pada perlindungan HAM. Begitu juga perbedaan terminologi dan definisi serta unsur-unsur suatu tindak pidana di Indonesia dengan negara lain. Dalam mendifinisikan tindak pidana penyuapan yang masuk

11 http:/ / www.interpol.go.id/id/berita / 749-mengenal-bantuan-hukumtimbal-balik-mutual-legal-assistance-in-criminal-matters, 16/11/2019.

12 http:/ / www.kemenkumham.go.id/berita/media-release-tandai-babakbaru-kerja-sama-hukum-menkumham-tanda-tangan-perjanjian-mutuallegal-assistance-in-criminal-matters, 17/11/2019.

13 Deddy Candra dan Arifin, "Kendala Pengembalian Aset Hasil Tindak Pidana Korupsi Transnasional”, Jurnal BPPK, 11, 1 (2018), hlm. 44. 
dalam kategori korupsi misalnya, terdapat perbedaan arti pada penyuapan, pencucian uang, dan korupsi. Terkait persoalan ini maka yang perlu dilakukan adalah negosiasi ulang perjanjian MLA. Terlebih jika terjadi misinterpretasi mengenai klausul permintaan dalam MLA. Hal ini penting dilakukan untuk menghindari perjanjian MLA yang tidak terlaksana karena perbedaan-perbedaan.

Persoalan lain yaitu mengenai hubungan aset dengan tindak pidana yang juga belum memiliki kepastian. Karena itu persoalan ini butuh adanya putusan pengadilan yang di dalamnya menjelaskan mengenai hubungan aset yang bersangkutan dengan tindak pidana yang dilakukan. Aset hasil tindak pidana korupsi yang tersimpan di negara lain dapat dilakukan pembekuan dan/atau dikembalikan jika terdapat nama dan keterangan spesifik tentang aset tersebut yang biasanya tidak tercantum dalam putusan pengadilan. Masalah benturan kepentingan juga dianggap mewarnai kendala pelaksanaan pengembalian aset, terutama terkait dengan pembentukan regulasi pendukung. Hal ini dianggap bahwa ada indikasi penyelewengan kekuasaan yang menyeret ekonomi kelas atas dengan poltik sebagai kekuatan kelas atas yang berkesinambungan dengan kekuatan politik, ekonomi, dan birokrasi meskipun secara faktual akan sulit dibuktikan. ${ }^{14}$

Dari beberapa uraian persoalan, artikel ini menitikberatkan pada satu poin utama terkait tidak optimalnya perjanjian MLA, yaitu tidak adanya perjanjian MLA dalam format bilateral. Berdasarkan keterangan Danardi Haryanto dari Direktorat Hukum dan Perjanjian Politik dan Keamanan, Kementerian Luar Negeri Republik Indonesia, diketahui bahwa ketidaklengkapan serta tidak rincinya klausul perjanjian MLA acapkali membuat negara termohon menolak untuk membantu. Karenanya, dalam teknisnya suatu permintaan harus dijelaskan secara terperinci mengenai hal-hal yang diinginkan dan disesuaikan dengan klausul yang sudah ada. Sebagai contoh, apabila negara pemohon membutuhkan bantuan dalam pembekuan rekening bank pelaku tindak pidana di negara yang dimohon, maka

14 Candra dan Arifin, "Kendala Pengembalian Aset”, hlm. 44 
dalam perjanjian MLA harus dijelaskan dari awal mengenai alasan pembekuan serta memberikan beberapa bukti untuk memperkuat alasan bahwa terdapat transaksi yang mencurigakan. ${ }^{15}$ Ini berarti meskipun sudah terdapat perjanjian MLA yang bersifat bilateral masih dibutuhkan kejelasan klausul sehingga tidak menjadi penghambat teknis pelaksanaanya di kemudian hari.

Berdasar beberapa persoalan tersebut, setidaknya ada dua langkah berurutan yang perlu dilakukan dalam menyusun perjanjian MLA agar lebih optimal. Pertama, tidak cukup bagi Indonesia untuk mengikatkan diri pada perjanjian MLA yang bersifat multilateral. Selain karena hambatan beragamnya sistem dan pemahaman terhadap terminologi tertentu, perjanjian MLA relatif lebih sulit untuk dituangkan secara terperinci, sehingga upaya untuk lebih meningkatkan efektivitas dan optimalisasi peran MLA perlu dibuat dalam format bilateral. Kedua, berdasarkan keterangan kendala teknis terkait klausul-klausul yang tidak terperinci dan detail dalam perjanjian secara bilateral, maka langkah optimalisasi berikutnya adalah menungkan klausul-klausul perjanjian MLA secara rinci dan cermat.

\section{Optimalisasi Peran Penegak Hukum dalam Pelaksanaan MLA}

Selain dalam aspek pembentukan perjanjian dan pelaksanaan dalam bentuk regulasi nasional (legal substance), hal yang perlu dioptimalkan juga adalah peran aparat penegak hukumnya sebagai struktur hukum (legal structure) seperti Kepolisian, Kejaksaan, Komisi Pemberantasan Korupsi dan beberapa institusi lain yang relevan. Kepolisian pada pelaksanaan MLA terbatas pada permintaan bantuan dilakukanya penggeledahan dan penyitaan. ${ }^{16}$ Wewenang ini tentu tidak akan

15 Wawancara dengan I. Danardi Haryanto, Kepala Subdirektorat Politik dan Kerja Sama Penegakan Hukum, Direktorat Hukum dan Perjanjian Politik dan Keamanan, Kementerian Luar Negeri Republik Indonesia, Jakrta, 4/12/2019.

16 Undang-Undang Nomor 1 Tahun 2006 tentang Bantuan Timbal Balik dalam Masalah Pidana, Pasal 3 ayat (2) huruf (f). 
operasional secara teknis karena tentu akan terjadi benturan yurisdiksi dengan kewenangan lembaga serupa di negara termohon sebagai pemilik yurisdiksi. Sehingga dalam konteks ini maka peran kepolisian dapat lebih dioptimakan pada fungsi kerjasama pencegahan yang salah satunya adalah dengan jalan menerapkan standar pertukaran informasi otomatis antarnegara.

Cakupan MLA meliputi upaya-upaya proses penyidikan, penuntutan, dan peradilan. Dalam proses pelaksanaan MLA, NCB-Interpol Indonesia berperan dalam proses penyidikan seperti pemeriksaan atau pemanggilan saksi, penggeledahan, dan penyitaan. Pemeriksaan atau pemanggilan saksi merupakan upaya dalam menghadirkan orang untuk mengidentifikasi dan mencari orang atau memberikan keterangan atau untuk membantu proses penyidikan. ${ }^{17}$ Hal tersebut juga bergantung pada peraturan yang berlaku di negara yang diminta dengan NCB-Interpol apakah dapat memenuhi secara langsung atau mengharuskan permintaan bantuan diajukan oleh Menteri Hukum dan HAM melalui saluran diplomatik.

Selain itu, pelaksanaan MLA di lingkungan Kejaksaan dilaksanakan oleh Biro Hukum dan Hubungan Luar Negeri, di bawah kewenangan Jaksa Agung Pembinaan. ${ }^{18}$ Sebagaimana diatur dalam UU Bantuan Timbal Balik (MLA), ruang lingkup Kejaksaan RI dalam mengajukan permintaan bantuan meliputi pengajuan permohonan bantuan; pemberian informasi terkait orang terduga ikut serta dalam suatu perkara yang sedang berada dalam proses penyidikan, penuntutan, atau persidangan; pemberian informasi mengenai alat bukti yang berada di negara asing; pemeriksaan terhadap seseorang yang telah memberikan keterangan atau menyerahkan barang bukti berkaitan dengan MLA; menghadirkan seseorang yang berhubungan dengan perkara dalam MLA ke Indonesia untuk kelancaran pemberian keterangan dan penyerahan barang bukti; dan pengajuan permohonan untuk eksekusi penetapan pengadilan yang dapat

17 Undang-Undang Nomor 1 Tahun 2006 tentang Bantuan Timbal Balik dalam Masalah Pidana, Pasal 3 ayat (2) huruf (a) dan (d).

18 Peraturan Jaksa Agung Republik Indonesia Nomor PER-009/ A/JA/ 01 / 2011 tentang Organisasi dan Tata Kerja Kejaksaan Republik Indonesia. 
berupa perampasan aset, pengenaan denda, atau penyerahan uang pengganti.

Dalam konteks tindak pidana korupsi, KPK berwenang dalam tindakan penyelidikan, penyidikan, dan penuntutan. Kewenangan tersebut sama dengan kewenangan Kepolisian di tingkat penyidikan dan kewenangan Kejaksaan di tingkat penuntutan dalam tindak pidana korupsi. ${ }^{19}$ KPK sebagai salah satu institusi penegak hukum memiliki kewenangan dalam perampasan aset hasil tindak pidana korupsi di luar negeri dengan mengajukan permintaan bantuan melalui Kementerian Hukum dan HAM yang berperan sebagai koordinator dalam hal pengajuan permohonan MLA kepada negara asing maupun menangani permohonan bantuan MLA negara asing ke Indonesia. ${ }^{20}$

Selain Kepolisian, Kejaksaan dan KPK, Kementerian Hukum dan HAM menjadi Central Authority atau Otoritas Pusat dalam menangani permasalahan MLA di Indonesia. ${ }^{21}$ Uraian tugas tersebut didasarkan pada Surat Keputusan Menteri Hukum dan HAM Nomor M.HH.04. AH.08.02 Tahun 2009 tentang Pelaksana Tugas di Bidang Ekstradisi dan Bantuan Timbal Balik dalam Masalah Pidana di Kementerian Hukum dan HAM. Kementerian lain yang juga berperan penting adalah Kementerian Luar Negeri. Peran-peran yang dijalankan antara lain adalah pembentukan perjanjian MLA tingkat bilateral, regional, dan internasional; negosiator perumusan klausul perjanjian MLA; saluran diplomatik; penyusunan dan penyampaian MLA; dan monitoring dalam permintaan MLA. ${ }^{22}$ Walaupun tidak memiliki kaitan terhadap penegakan hukum, Kementerian Luar Negeri dalam proses pelaksanaan MLA memiliki peran sebagai lembaga representasi pemerintah di hadapan negara asing.

19 Undang-Undang Nomor 30 Tahun 2002 tentang Komisi Pemberantasan Korupsi, Pasal 51.

20 Undang-Undang Nomor 1 Tahun 2006 tentang Bantuan Timbal Balik dalam Masalah Pidana, Pasal 1 angka 10.

21 Ika Yuliana Susilawati, "Perampasan Aset Hasil Tindak Pidana Korupsi di Luar Negeri Melalui Bantuan Timbal Balik (Mutual Legal Assistance)”, Jurnal IUS Kajian Hukum dan Keadilan, 4, 2 (2016), hlm. 147.

22 Susilawati, "Perampasan Aset Hasil Tindak Pidana”, hlm. 148. 
Selain instansi-instansi tersebut, Pusat Pelaporan Analisis Transaksi Keuangan (PPATK) juga merupakan instansi yang berperan penting. PPATK berperan memberikan informasi transaksi keuangan dalam rangka penelusuran aset (aset tracing) baik ketika proses analisis transaksi keuangan maupun ketika proses penyidikan, penuntutan, dan persidangan. ${ }^{23}$ Pengaksesan khusus database diberikan oleh Kapolri dan Interpol untuk PPATK sangat penting dalam memperkaya dan memperatajam analisis PPATK terhadap transaksi keuangan yang mencurigakan. ${ }^{24}$ Kemudian informasi yang telah didapat dilimpahkan ke penegak hukum untuk dilakukan penyelidikan, yang diteruskan penyidikan, dan proses peradilan.

Dalamkaitanya denganoptimalisasiperanaparatpenegakhukum dan fungsi-fungsinya sebagaimana diuraikan, beberapa persoalan yang masih harus diselesaikan adalah, pertama, kurangnya kesediaan negara-negara maju dalam membantu proses upaya pengembalian aset selain lambannya kerjasama antarinstitusi bersangkutan dengan pengembalian aset. Untuk itu kiranya perlu kesepakatan bersama untuk mengajukan permohonan baik dari Kepolisian, Kejaksaan, maupun KPKkepada Kementerian Hukum dan HAM sebagai otoritas pusat. Dalam meraih kesepakatan ini terkadang terhalang masalah sektoral yang diikuti kepentingan politik tiap institusi menjadikan waktu yang dibutuhkan terlalu lama. ${ }^{25}$

Kedua, sebagai salah satu konsep yang sudah diterapkan di beberapa negara lain, prinsip pendukung seperti Non Conviction Based (NCB) Asset Forfeiture belum diterapkan di peraturan Indonesia. Sehingga penerapan mekanisme $N C B$ asset forfeiture yang dianggap dapat menjadi alternatif langkah optimalisasi pengembalian aset belum dapat dioptimalkan dengan signifikan oleh penegak hukum dalam perkara tindak pidana korupsi. ${ }^{26}$

Sistem kerahasiaan perbankan (bank secrecy) juga masih dianggap menjadi kendala. Setiap bank di seluruh negara memiliki

23 Susilawati, "Perampasan Aset Hasil Tindak Pidana”, hlm. 151.

24 Suliswati, "Perampasan Aset Hasil Tindak Pidana”, hlm. 149.

25 Candra dan Arifin, "Kendala Pengembalian Aset", hlm. 44.

26 Candra dan Arifin, "Kendala Pengembalian Aset”, hlm. 44. 
aturan yang dapat melindungi aset dan identitas nasabah sehingga seringkali penegak hukum kesulitan dalam melacak aset koruptor karena harta hasil kejahatannya dilindungi oleh aturan kerahasiaan bank. Hal ini dinilai akibat UNCAC 2003 yang belum dilaksanakan melalui peraturan perundang-undangan di Indonesia sekalipun sudah diratifikasi melalui Undang-Undang Nomor 7 Tahun 2006. Kajian analisis kesenjangan menunjukkan bahwa adanya beberapa penyesuaian yang perlu segera dilakukan dalam memenuhi klausulklausul pada UNCAC 2003 dikhususkan di bidang kriminalisasi dan peraturan perundang-undangan. Selain itu, proses pengembalian aset hasil tindak pidana korupsi di luar negeri memakai mekanisme dan prosedur yang panjang, biaya yang besar, serta sumber daya manusia yang tidak terbatas. ${ }^{27}$

Dari uraian yang dilakukan, setidaknya ada dua persoalan utama yang berpotensi mengganggu optimalisasi peran aparat penegak hukum. Pertama adalah potensi friksi yang terjadi antar aparat penegak hukum karena memiliki kewenangan yang tumpang tindih (overlapping). Untuk hal ini, langkah yang perlu dilakukan tentu harus ada koordinasi antarlembaga atau dalam tahapan lebih lanjut dibuat regulasi spesifik yang mengatur pelaksana isu terkait jika diperlukan. Kedua adalah lemahnya perjanjian MLA sebagai dasar pelaksanaan para aparat penegak hukum. Sebagaimana yang telah diuraikan sebelumnya bahwa pelaksanaan perjanjian MLA acapkali terkendala karena alasan-alasan klausul MLA yang tidak rinci sehingga tidak dapat dilaksanakan. Untuk itu aparat penegak hukum tentu baru akan optimal berperan manakala dasar hukum pelaksanaan untuk menjalankan fungsinya yaitu perjanjian MLA juga memberikan jaminan bahwa perjanjian tersebut secara operasional tidak memiliki kendala.

\section{Prospek Pelaksanaan Non-Conviction Based (NCB) Asset Forfeiture dalam Pengembalian Aset}

Salah satu alternatif yang dapat didorong dalam upaya pengembalian

27 Candra dan Arifin, "Kendala Pengembalian Aset", hlm. 44. 
aset negara dalam tindak pidana korupsi termasuk di Indonesia adalah penerapan prinsip Non-Conviction Based (NCB) Asset Forfeiture, selain juga Convicted Based Asset Forfeuture, ${ }^{28}$ yang sebenarnya bisa dijadikan sebagai muatan substantif dalam perjanjian MLA. NCB Asset Forfeiture merupakan salah satu mekanisme pengembalian aset dengan pendekatan perdata yang tidak diperlukannya putusan pengadilan yang berkekuatan hukum tetap. Mekanisme ini dianggap dapat lebih efektif dibanding dengan pendekatan pidana (criminal forfeiture) yang standar pembuktiannya sangat tinggi pada proses persidangan. Dalam implementasinya, NCB Asset Forfeiture menggunakan sistem pembuktian terbalik untuk melakukan pembuktian kasus korupsi yaitu dengan mewajibkan terdakwa agar dapat membuktikan bahwa aset kekayaan yang dimilikinya bukan hasil dari suatu kejahatan. ${ }^{29}$

Konsep NCB asset forfeiture pada pokoknya merupakan suatu mekanisme perampasan aset tanpa adanya proses hukum pidana terlebih dahulu. Dalam hal ini, perampasan dilakukan secara perdata (in rem) dan ditujukan pada aset pelaku tindak pidana. Hal penting dari mekanisme ini yaitu bahwa adanya kejelasan harta tersebut merupakan harta tercemar (legally tainted property) atau didapat melalui tindak kejahatan. Lahirnya konsep NCB asset forfeiture dilatarbelakangi dengan pergeseran paradigma penegakan hukum yang pada awalnya berkiblat atau mengarah pada pelaku (follow the suspect) menjadi mengarah pada uang atau kerugian (follow the money). Ini menjadi penting karena tindak pidana korupsi maupun tindak pidana pencucian uang menyebabkan kerugian keuangan bagi negara oleh karena itu uang hasil tindak pidana tersebut harus dikembalikan kepada negara yang di sisi lain sering kali tampak kondisi pelakunya tidak dapat diadili terlebih dahulu. ${ }^{30}$ Mekanisme ini ditempuh secara

28 Bismar Nasution, "Pengembalian Aset Hasil Tindak Korupsi melalui Civil Forfeiture”, https://jurnal.kpk.go.id/Dokumen/SEMINAR_ ROADSHOW / Asset-recovery-melalui-civil-forfeiture-Bismar-Nasution. pdf, diakses $05 / 05 / 2020$.

29 Romli Atmasasmita, Sekitar Masalah Korupsi Aspek Nasional dan Aspek Internasional (Bandung: Mandar Maju, 2004), hlm. 58.

30 July Wiarti, "Non-Conviction Based Asset Forfeiture sebagai Langkah untuk Mengembalikan Kerugian Negara (Perspektif Analisis Ekonomi terhadap 
terpisah dari proses peradilan pidana dengan bukti yang menyatakan bahwa telah tercemarnya suatu properti oleh tindak pidana. Pencemaran ini bertumpu pada taint doctrine, yaitu suatu doktrin yang meyakini bahwa tindak pidana dianggap mengotori properti yang digunakan atau diperoleh dari tindak pidana tersebut.

Di beberapa negara, seperti Swiss, pengembalian aset diatur baik dengan dasar pemidanaan dan tidak dengan pemidanaan. Dua cara tersebut tertuang dalam sumber hukum utama pada hukum pidana Swiss yaitu Code Penal tertanggal 21 Desember 1937 (Undang-Undang Tahun 1937) sebagaimana tercantum pada Pasal 123 Paragraf 1 dan 3 Konstitusi Federal (Amandemen Nomor 1 tanggal 30 September 2011). ${ }^{31}$ Perampasan dengan pemidanaan maupun tanpa pemidanaan berdasarkan Pasal 70 hingga Pasal 72 Undang-Undang Tahun 1937. Aset yang dapat dilakukan penyitaan merupakan aset hasil kejahatan. Selama aset dapat dilacak, maka aset tersebut dapat disita apabila telah terbukti berkaitan dengan kejahatan. Namun, apabila hal tersebut tidak terbukti maka tidak dimungkinkan lagi adanya perampasan. Selain itu dalam hal pembuktian, Swiss menerapkan pembuktian kriminal standar ganda dalam perkara perampasan aset. Hal ini berbeda dengan penerapan pembuktian di negara common law yang lebih cenderung menerapkan standar pembuktian civil balances probabilities. $^{32}$

Sedangkan di Inggris, hukum penyitaan aset didasarkan pada Undang-Undang Hasil Tindak Pidana Kejahatan Tahun 2002 (Proceed of Crime Act 2002). Sesuai dengan Undang-Undang tersebut, perintah terhadap penyitaan akan dilakukan apabila pengadilan (crown court) memintanya. Dalam Proceed of Crime Act 2002, Inggris memperkenalkan pengembalian aset yang memungkinkan para aparat penegak hukum untuk menarik kembali harta benda yang mewakili "harta benda yang diperoleh dengan tindakan yang mela-

Hukum”, UIR Law Review, 1, 1 (2017), hlm. 104.

31 Supardi, Perampasan Harta Hasil Korupsi Perspektif Hukum Pidana yang Berkeadilan (Jakarta: Prenadamedia Group, 2018), hlm. 205.

32 Supardi, Perampasan Harta Hasil Korupsi, hlm. 207. 
wan hukum". ${ }^{33}$

Pada praktiknya, mekanisme NCB Asset Forfeiture di Inggris diberlakukan bahwa aset dapat dibekukan berkaitan dengan perkara penyitaan yang tidak berdasarkan keyakinan. Hal tersebut dilakukan dengan diperolehnya penentuan perintah larangan dari aset yang relevan dari Pengadilan Tinggi. Pengadilan Inggris dapat membuat perintah larangan sehubungan dengan aset jika yakin bahwa: a) aset tersebut relevan dengan identifikasi yang ada dalam permintaan; b) belum ditentukannya proses pengambilan aset untuk dipulihkan dengan cara pengembalian perdata di Inggris. ${ }^{34}$

Aset dianggap sebagai aset yang relevan apabila terdapat alasan yang masuk aset gagal dan kurangnya bukti untuk mengawali gugatan pidana. ${ }^{35}$ Gugatan perdata dilakukan dengan penggunaan mekanisme pembuktian terbalik dengan cara pemerintah mengajukan bukti untuk menjelaskan aset tersebut merupakan hasil, berkaitan atau dipakai dalam suatu kejahatan. ${ }^{36}$

Rentang waktu tersebut dirasa patut untuk pihak ketiga ketahui bahwa akan dilakukannya perampasan aset melalui pengadilan. Jika dalam waktu tersebut terdapat pihak ketiga yang berkeberatan dengan adanya perampasan, maka yang bersangkutan dapat mengajukan upaya hukum ke pengadilan dengan menghadirkan alat bukti dengan kriteria masuk akal dan dapat dipercaya. Perintah penyitaan sesuai dengan NCB Asset Forfeiture harus didasarkan pada dugaan perilaku kriminal yang juga diakui sebagai tindak pidana di Inggris.

Sedangkan di Australia, penggunaan perampasan perdata terdapat ketentuan dalam Amandemen Undang-Undang Kejahatan

33 Supardi, Perampasan Harta Hasil Korupsi, hlm. 212.

34 Stolen Asset Recovery Initiative (StAR), "Obtaining Assistance from the UK in Asset Recovery: A Guide for International Partners”, hlm. 13, lihat dalam https: / / star.worldbank.org/sites/star/files/ar_guide_uk_updated_ dec_2017.pdf, diakses pada 24/10/2019

35 Anthony Kennedy, "An Evaluation of the Recovery of Criminal Proceeds in the United Kingdom", Journal of Money Laundering Control, 10, 1 (2007), hlm. 37.

36 Anthony Kennedy, "Designing a Civil Forfeiture System: An Issues List for Policymakers and Legislators", Journal of Financial Crime, 13, 2 (2006), hlm. 140. 
terbaru (Kejahatan Serius dan Teroganisasi) yang merupakan hasil amandemen dari Proceeds of Crime Act 2002 (Undang-Undang Australia). Namun, sebagian besar negara bagian memiliki hukum versi mereka sendiri yang berhubungan dengan perampasan perdata, dan beberapa mengacu langsung ke perundang-undangan Australia. ${ }^{37}$

Beberapa substansi yang diatur dalam regulasi tersebut seperti termuat dalam bagian 179 B dari Proceeds of Crime Act 2002 yang menyatakan bahwa pengadilan harus membuat perintah awal mengenai kekayaan yang tidak dapat dijelaskan (unexplained wealth order) yang membutuhkan seseorang muncul untuk menjelaskannya sehingga memungkinkan Pengadilan dalam memutuskan apakah akan membuat atau tidak urutan kekayaan yang tidak dapat dijelaskan berkaitan dengan orang tersebut di mana Direktur Penuntut Publik Persemakmuran (DPP) telah meminta perintah tersebut. Selain itu bahwa Pengadilan harus yakin bahwa petugas yang berwenang dalam DPP memiliki alasan wajar untuk mencurigai bahwa total kekayaan seseorang melebihi nilai kekayaan yang diperoleh secara sah.

Dalam bagian $179 \mathrm{E}$, pengadilan akan membuat penetapan apabila kekayaan tersebut tidak dapat dijelaskan mengharuskan orang tersebut wajib membayar ke Persemakmuran jika Pengadilan telah membuat urutan awal kekayaan yang tidak dapat dijelaskan oleh orang yang bersangkutan. Apabila Pengadilan telah membuat perintah terakhir, ditentukan berapa jumlah yang harus dibayar orang tersebut ke Persemakmuran. Jumlah tersebut merupakan selisih antara total kekayaan dan jumlah aset yang diyakini Pengadilan tidak melanggar hukum.

Dalam konteks perjanjian internasional, sejak 2003 bentuk pengejaran keuntungan ilegal tersebut diatur lebih lanjut di dalam UNCAC. Pada Pasal 54 ayat (1) UNCAC diatur mengenai ketentuan bahwa semua negara peserta harus mempertimbangkan untuk mengambil tindakan yang dinilai mendesak sehingga pengembalian aset hasil korupsi dengan kemungkinan tidak perlu adanya proses

37 Anthony Davidson Gray, "Forfeiture Provisions and the Criminal/Civil Divide”, New Criminal Law Revies, 15, 1 (2012), hlm. 34. 
pidana pada perkara, akibat tidak dapat dituntutnya pelaku yang beralasan kematian, pelarian, atau berkaitan dengan perkara lainnya. Menurut UNCAC, mekanisme NCB asset forfeiture ini dapat digunakan sebagai sarana untuk merampas serta memulihkan aset hasil tindak pidana korupsi di semua yurisdiksi.

Secara teknis, cara paling tepat dan mudah untuk melaksanakan mekanismeNCBassetforfeitureadalahdimulaidengan hartayangdiduga hasil tindak kejahatan diblokir dan ditarik dari arus perekonomonian melalui penyitaan kepada pengadilan yang sebelumnya dimohonkan terlebih dahulu. Selanjutnya pengadilan memutuskan harta tersebut sebagai harta tercemar. Setelah dinyatakan sebagai harta tercemar, pengadilan mengumumkan melalui media publik selama waktu yang cukup yaitu tidak lebih 30 hari. ${ }^{38}$ Perampasan jalur perdata (in rem) adalah tindakan yang ditempuh apabila proses pidana diikuti dengan pengambilalihan aset (confiscation) tidak dapat dilakukan karena pemilik aset telah meninggal dunia; proses pidana yang berakhir karena terdakwa dinyatakan bebas; penuntutan pidana dinyatakan berhasil namun, pengambilalihan sah untuk membuktikan bahwa dialah yang memiliki harta tersebut disertai penjelasan bagaimana memperolehnya. ${ }^{39}$

Bagi Indonesia, dalam konteks perjanjian internasional, beberapa bidang yang terkait dengan politik hukum dan keamanan baru dapat dilaksanakan setelah adanya ratifikasi yang di Indonesia dilaksanakan melalui proses transformasi menjadi hukum nasional terlebih dahulu. Di dalam sistem peraturan perundang-perundangan yang berlaku di Indonesia, pengaturan mengenai NCB Asset Forfeiture memang belum cukup memadai sehingga penerapan mekanisme NCB Asset Forfeiture belum dapat dioptimalkan oleh penegak hukum terutama dalam perkara tindak pidana korupsi meski menurut Yunus Husein

38 Sudarto dan Hari Purwadi, "Mekanisme Perampasan Aset dengan Menggunakan Non-Conviction Based Asset Forfeiture sebagai Upaya Pengembalian Kerugian Negara Akibat Tindak Pidana Korupsi”, Jurnal Pasca Sarjana Hukum UNS, 5, 1 (2017), hlm. 112; Yenti Garnasih, "Asset Recovery Act sebagai Strategi dalam Pengembalian Aset Hasil Tindak Pidana”, Jurnal Legislasi Indonesia, 7, 4 (2010), hlm. 630.

39 Bismar Nasution, "Pengembalian Aset Hasil Tindak Korupsi”. 
tidak berarti sama sekali tidak dapat dipraktikan. Beberapa regulasi menurutnya dapat menjadi dasar pelaksanaan prinsip tersebut meski tidak optimal. ${ }^{40}$

Sebagai salah satu bentuk upaya yang untuk lebih mengoptimalkan pelaksanaan NCB maka digulirkan pembahasan Rancangan Undang-Undang Perampasan Aset Tindak Pidana. Dalam Naskah Akademik RUU Perampasan Aset Tindak Pidana substansi pelaksanaan NCB asset forfeiture yang merupakan salah satu rekomendasi UNCAC. ${ }^{41}$ Undang-Undang 24 Tahun 2000 tentang Perjanjian Internasional memberikan pengaturan bahwa dalam konteks pembentukan kaidah hukum baru, maka pengesahan perjanjian internasional harus dituangkan dalam bentuk UndangUndang. Namun demikian, sebagai sebuah rancangan produk hukum, RUU Perampasan Aset Tindak Pidana tersebut meskipun nanti telah disahkan maka masih merupakan klaim unilateral. Jika dilihat prospek pelaksanaanya terutama terkait asset yang berada di luar negeri tentu masih harus memakai perangkat regulasi tambahan karena akan sangat terkait dengan yurisdiksi Negara lain. Untuk itu salah satu yang penting selain pembentukan regulasi nasional adalah pembentukan perangkat hukum yang lebih teknis yaitu MLA baik yang bersifat bilateral, trilateral, maupun multilateral.

\section{E. Kesimpulan}

Artikel ini menyimpulkan, Bantuan Hukum Timbal Balik atau Mutual Legal Assistance (MLA) merupakan salah satu perangkat penting dalam proses pengembalian aset hasil korupsi yang ada di luar negeri. Namun demikian, optimalisasi peran MLA masih memerlukan beberapa langkah seperti menerapkan MLA dalam format bilateral

40 Yunus Husein, "Penjelasan Hukum tentang Perampasan Aset Tanpa PemidanaandalamPerkaraTindakPidanaKorupsi”, LaporanPenelitianPusat Penelitian dan Pengembangan Hukum dan Kebijakan dan Pusat Penelitian dan Pengembangan Hukum dan Peradilan Mahkamah Agung Republik Indonesia, 2019, https://pshk.or.id/wp-content/uploads/2019/04/ Restatement_Perampasan-Aset-Tanpa-Pemidanaan_2019.pdf, diakses 25/10/2019, hlm. 65-66.

41 Husein, "Penjelasan Hukum tentang Perampasan Aset”, hlm. 81. 
dan penjabaran teknis yang lebih detail dan terperinci, serta alternatif untuk memuat konsep Non-Conviction Based Asset Forfeiture (NCB) sebagai muatan substantif dalam setiap perjanjian MLA. Indonesia merupakan salah satu pihak UNCAC, dan saat ini memiliki RUU Perampasan Aset yang di dalamnya juga menawarkan mekanisme NCB asset forfeiture sebagai jalan keluar yang dapat ditempuh dalam proses pengembalian aset sehingga harus dibuat terlebih dahulu regulasi nasional dan MLA sebagai pendukung pelaksanaan. Selain itu optimalisasi peran penegak hukum juga menjadi keharusan, antara lain mengubah perspektif penegakan hukum dari in personam menjadi in rem; kerja sama intensif antarlembaga penegak hukum baik nasional maupun internasional. Untuk itu penyelarasan peraturan perundang-undangan nasional berdasarkan ketentuan internasional dalam konvensi sebagai dasar hukum pelaksana juga menjadi penting.

\section{Daftar Pustaka}

\section{Artikel, Buku, dan Laporan}

Atmasasmita, Romli. Sekitar Masalah Korupsi Aspek Nasional dan Aspek Internasional. Bandung: Mandar Maju, 2004.

Arifin, Ridwan, Indah Sri Utari, dan Heri Subondo. "Upaya Pengembalian Aset yang Berada di Luar Negeri (Asset Recovery) dalam Penegakan Hukum Pemberantasan Korupsi di Indonesia”. Indonesian Journal of Criminal Law, 1, 1 (2016): 105-137. DOI: 10.15294/ijcls.v1i1.10810.

Candra, Deddy dan Arifin. "Kendala Pengembalian Aset Hasil Tindak Pidana Korupsi Transnasional”. Jurnal BPPK, 11, 1 (2018): 28-55. Garnasih, Yenti. "Asset Recovery Act sebagai Strategi dalam

Pengembalian Aset Hasil Tindak Pidana". Jurnal Legislasi Indonesia, 7, 4 (2010): 629-643.

Husein, Yunus. "Penjelasan Hukum tentang Perampasan Aset Tanpa Pemidanaan dalam Perkara Tindak Pidana Korupsi”. Laporan Penelitian Pusat Penelitian dan Pengembangan Hukum dan Kebijakan dan Pusat Penelitian dan Pengembangan Hukum 
dan Peradilan Mahkamah Agung Republik Indonesia Tahun 2019. Https://pshk.or.id/wp-content/uploads/2019/04/ Restatement_Perampasan-Aset-Tanpa-Pemidanaan_2019.pdf. Diakses 25/10/2019.

Jaya, Nyoman Serikat Putra. Beberapa Pemikiran ke Arah Pengembangan Hukum Pidana. Bandung: Citra Aditya Bakti, 2008.

Kennedy, Anthony. "An Evaluation of the Recovery of Criminal Proceeds in the United Kingdom". Journal of Money Laundering Control, 10, 1 (2007): 33-46. DOI: 10.1108/13685200710721854.

Kennedy, Anthony. "Designing a Civil Forfeiture System: An Issues List for Policymakers and Legislators". Journal of Financial Crime, 13, 2 (2006): 132-163. DOI: 10.1108/13590790610660863.

Laoly, Yasonna H. Diplomasi Mengusut Kejahatan Lintas Negara. Jakarta: Pustaka Alvabet, 2019.

Nasution, Bismar. "Pengembalian Aset Hasil Tindak Korupsi Melalui Civil Forfeiture”. Https: / jurnal.kpk.go.id/Dokumen/ SEMINAR_ROADSHOW / Asset-recovery-melalui-civilforfeiture-Bismar-Nasution.pdf. Diakses 05 / 05/2020.

Pardede, Marulak dan Sri Sedjati. "Efektivitas Perjanjian Kerjasama Timbal Balik Dalam Rangka Kepentingan Nasional”. Laporan Penelitian BPHN Tahun 2012. Https: / www.bphn.go.id/ data/ documents/lit_2012_-_7.pdf. Diakses 28/10/2019.

Priyatno, Dwidja. "Non Conviction Based (NCB) Asset Forfeiture for Recovering the Corruption Proceeds in Indonesia". Journal of Advanced Research in Law and Economics, 9, 1 (2018): 219-233. DOI: 10.14505/ / jarle.v9.1(31).27.

Rustamaji, Muhammad dan Bambang Santoso. "The Study of Mutual Legal Assistance Model and Asset Recovery in Corruption Affair”. Indonesian Journal of Criminal Law, 4, 2 (2019): 155-160. DOI: 10.15294 / ijcls.v4i2.18719.

Saputra, Refki. "Tantangan Penerapan Perampasan Aset Tanpa Tuntutan Pidana (Non-Conviction Based Asset Forfeiture) dalam RUU Perampasan Aset di Indonesia”. Jurnal Antikorupsi Integritas, 3, 1 (2017): 115-130. DOI: 10.32697/integritas.v3i1.158.

Stolen Asset Recovery Initiative (StAR). “Obtaining Assistance from 
the UK in Asset Recovery: A Guide for International Partners". Https: / / star.worldbank.org/sites / star/files / ar_guide_uk_ updated_dec_2017.pdf. Diakses 24/10/2019.

Sudarto dan Hari Purwadi. "Mekanisme Perampasan Aset dengan Menggunakan Non-Conviction Based Asset Forfeiture sebagai Upaya Pengembalian Kerugian Negara Akibat Tindak Pidana Korupsi”. Jurnal Pasca Sarjana Hukum UNS, 5, 1 (2017): 109-118. Sukardi, Irma. "Mekanisme Bantuan Timbal Balik dalam Masalah Pidana (Mutual Legal Assistance) dalam Perampasan Aset Hasil Tindak Pidana Korupsi Berdasarkan Undang-Undang Nomor 1 Tahun 2006 tentang Bantuan Timbal Balik dalam Masalah Pidana”. Tesis, Universitas Indonesia, Jakarta, 2012.

Supardi. Perampasan Harta Hasil Korupsi Perspektif Hukum Pidana yang Berkeadilan. Jakarta: Prenadamedia Group, 2018.

Susilawati, Ika Yuliana. "Perampasan Aset Hasil Tindak Pidana Korupsi di Luar Negeri Melalui Bantuan Timbal Balik (Mutual Legal Assistance)". Jurnal IUS Kajian Hukum dan Keadilan, 4, 2 (2016): 138-151. DOI: 10.12345/ius.v4i2.281.

Wiarti, July. "Non-Conviction Based Asset Forfeiture Sebagai Langkah untuk Mengembalikan Kerugian Negara (Perspektif Analisis Ekonomi terhadap Hukum”. UIR Law Review, 1, 1 (2017): 101109. DOI: 10.25299/ulr.2017.1.01.154.

Zuhir, Mada Apriandi. "United Nations Convention Against Corruption, Kewajiban Internasional dan Diplomasi Indonesia terkait Komitmen anti Korupsi”. Bahan Seminar Diseminasi United Nations Convention Against Corruption (UNCAC), diselenggarakan Fakultas Hukum Universitas Sriwijaya dan Komisi Pemberantasan Korupsi, 11/6/2020.

\section{Peraturan Hukum}

Republik Indonesia. Undang-Undang Nomor 2 Tahun 2002 tentang Kepolisian Negara Republik Indonesia. Lembaran Negara Tahun 2002 Nomor 2, Tambahan Lembaran Negara Republik Indonesia Nomor 4168.

Republik Indonesia. Undang-Undang Nomor 30 Tahun 2002 tentang 
Komisi Pemberantasan Korupsi. Lembaran Negara Tahun 2002 Nomor 137, Tambahan Lembaran Negara Nomor 4250.

Republik Indonesia. Undang-Undang Nomor 1 Tahun 2006 tentang

Bantuan Timbal Balik dalam Masalah Pidana. Lembaran Negara Tahun 2006 Nomor 18 Tambahan Lembaran Negara Republik Indonesia Nomor 4607.

Republik Indonesia. Undang-Undang Nomor 7 tahun 2006 tentang Pengesahan United Nations Convention Against Corruption, 2003, (Konvensi Perserikatan Bangsa-Bangsa Anti Korupsi, 2003), Lembaran Negara Tahun 2006 Nomor 32 Tambahan Lembaran Negara Republik Indonesia Nomor 4620.

Republik Indonesia, Kejaksaan Agung. Peraturan Jaksa Nomor PER009/ A/JA/ 01 / 2011 tentang Organisasi dan Tata Kerja Kejaksaan Republik Indonesia.

Republik Indonesia, Kepolisian Negara. Peraturan Kepala Kepolisian

Nomor 21 Tahun 2010 tentang Susunan Organisasi dan Tata Kerja Satuan Organisasi pada Tingkat Markas Besar Kepolisian Negara Republik Indonesia.

\section{Hasil Wawancara}

Hasil wawancara dengan I. Danardi Haryanto, Kepala Subdirektorat Politik dan Kerja Sama Penegakan Hukum, Direktorat Hukum dan Perjanjian Politik dan Keamanan, Kementerian Luar Negeri Republik Indonesia, Jakarta, 4/12/ 2019. 